УДК 303.722.3:130.2

\section{Цитування:}

Уварова Т. І. Дослідження культури в парадигмі багатовимірності. Вісник Національної академії керівних кадрів культури і мистеитв : наук. журнал. № 2. Київ : ІДЕЯ ПРИНТ, 2020. С. 37-42.

Uvarova T. (2020). Cultural research within the multidimensionality paradigm. National Academy of Culture and Arts Management Herald: Science journal, 2, 37-42 [in Ukrainian].
Уварова Тетяна Іванівна,

кандидат мистецтввознавства, доиент кафедри мистеитввознавства та загальногуманітарних дисииплін

Міжнародного гуманітарного університету, м. Odeca

ORCID: https://orcid.org/0000-0003-2628-7399 skalatatjana@ukr.net

\title{
ДОСЛІДЖЕННЯ КУЛЬТУРИ В ПАРАДИГМІ БАГАТОВИМІРНОСТІ
}

Мета дослідження полягає у розробці нової моделі дослідження культури, побудованої на парадигмі багатовимірності, що склалася у філософії. Методологія дослідження полягає у обгрунтуванні багатовимірності як методу дослідження культури. Науковою новизною $є$ осмислення методу багатовимірності та його дослідницького потенціалу в культурології. Висновки. Метод багатовимірності не використовувався у дослідженнях культури. У визначенні "багатовимірність" існує термінологічна неузгодженість і понятійна розрізненість. У гуманітарних дослідженнях поняття "багатовимірність" вживається метафорично. У результаті наукової розвідки був декларований евристичний потенціал багатовимірності як методу дослідження культури, окреслені перспективи його застосування у методології культурології.

Ключові слова: багатовимірність, багатовимірний простір, багатовимірний метод, багатовимірність культури.

Уварова Татьяна Ивановна, кандидат искусствоведения, доцент кафедры искусствоведения и общегуманитарных дисчиплин Международного гуманитарного университета, г. Одесса

Исследование культуры в парадигме многомерности

Цель статьи состоит в разработке методологической модели культурологического исследования, построенной на парадигме многомерности, которая сложилась в философии. Методология исследования основывается на обосновании многомерности как метода исследования культуры. Научной новизной является осмысление метода многомерности и его исследовательского потенциала в культурологии. Выводы. Метод многомерности не использовался в исследованиях культуры. В определении "многомерность" существует терминологическая неопределенность и понятийная разрозненность. В гуманитарных исследованиях понятие "многомерность" употребляется метафорично. В результате научного исследования был декларирован эвристический потенциал многомерности как метода исследования культуры, очерчены перспективы его применения в методологии культурологии.

Ключевые слова: многомерность, многомерное пространство, многомерный метод, многомерность культуры.

Uvarova Tetiana, Ph.D. of Arts, Assistant professor of the department of arts and humanitarian studies of International Humanitarian University, Odesa

Cultural research within the multidimensionality paradigm

The purpose of the article is to develop a methodological model of the research of culture within cultural studies, built on the paradigm of multidimensionality, which has developed in philosophy. The methodology is to introduce multidimensionality as a method of studying culture. The scientific novelty is the comprehension of the method of multidimensionality and its research potential in culturology. Conclusions. The method of multidimensionality was not used in cultural studies. In the definition of "multidimensionality," there is a terminological inconsistency and conceptual difference. As a result of scientific research, the heuristic potential of multidimensionality was declared as a method of studying culture, outlined prospects for its application in the methodology of cultural studies.

Key words: multidimensionality, multidimensional space, multidimensional method, the multidimensionality of culture.

Актуальність теми дослідження. Сьогодні багатовимірність розглядається як елемент парадигмального тренду та "має усі передумови, щоб набути фундаментального статусу. Ії слід розглядати у якості ключового терміну нової парадигми" [12, 131]. Виходячи з розуміння багатовимірності як загальнокультурної парадигми, пропонується наукове освоєння багатовимірності застосувати як дослідницький метод у культурології. Оскільки дослідження 
феномену культури стикається 3 необхідністю вибору адекватних підходів і методів, здатних охопити всі аспекти досліджуваних явищ, враховуючи їх цілісність та взаємозалежність. У цей час немає єдиного бачення того, яким чином можна здійснити саме "багатовимірний" аналіз, який би дав змогу поєднати дослідження об’єктивних явищ культури $з$ особливостями їх суб'єктивних проявів. Тому розгляд багатовимірності у якості нового методу, на нашу думку, може бути цілком перспективним для вивчення такого складного та багатогранного феномену як культура.

Мета дослідження. Проаналізувавши історію проникнення багатовимірності в дослідницькій практиці, можемо зробити деякі висновки. По-перше, незважаючи на широке введення в науковий дискурс ідей багатовимірності, багатовимірність культури в цих позиціях не експлікована. По-друге, можемо констатувати, що у наукових дослідженнях поняття "багатовимірність" визначається множинністю творчих інтерпретацій. Строкатість визначень лише підтверджує той факт, що "багатовимірність" ще знаходиться у стадії формування як концепт, а актуалізація різних аспектів багатовимірного аналізу в залежності від спектру наукових інтересів дослідника, та ракурсу дослідження, свідчить про початок становлення методології багатовимірності. Разом 3 тим, неузгодженість термінологічного базису, може призвести до смислового нагромадження та плутанини. Отже виникає потреба в уточнені поняття "багатовимірність" саме в контексті культурологічного знання.

Виклад основного матеріалу. Поняттєві пошуки "багатовимірності". Більшість визначень "багатовимірність", пов’язані 3 розумінням "багатовимірності" як того, що має декілька вимірів. Більш конкретним $\epsilon$ термінологічне розгортання багатовимірності у царині точних наук. Поняття "багатовимірний" використовується задля визначення однієї 3 множини як узагальнення у випадку з багатьма вимірами. У гуманітарній сфері воно, частіш за все, застосовується переважно як метафора, коли бажають підкреслити складність, багатогранність та "глибину" досліджуваного об'єкту. Також існує розуміння багатовимірності як "співвідношення суперечливих частин цілого", як "відносини між системою та їі окремими сферами, рівнями, підсистемами, кожна 3 яких є рівноцінним індивідуальним виміром того цілого, до якого вона входить"[10]; як категорія, що виражає "множинність незалежних i незвідних один до одного вимірів" [13]. Багатовимірний також тлумачиться як той, "який має додаткові нашарування рівнів, які $\epsilon$ невідомими"< .. >, що підкреслює факт наявності мірності, яка є більшою, ніж та, яка зафіксована у даний момент відповідної дослідницької ситуації" [1]. Тобто багатовимірність як перехід до освоєння нової мірності, тієї, що йде за існуючою.

У самому понятті "багатовимірність" закладено інструментальну природу, яка пов'язана з різноманіттям способів вимірювання. Адже за допомогою міри у вимірюване привноситься деяка впорядкованість через звернення до міри як певної величини, що $\epsilon$ одиницею виміру в конкретних умовах чогонебудь, ступінь чого-небудь, те, чим вимірюють що-небудь. Звідси постає питання: а чи правомірним є застосування мірності у контексті дослідження культури? Чи не $\epsilon$ "вимірність культури даремною абстракцією, яка не виконує операційну функцію наукового поняття"[2, 314]. Адже "вимірним є лише те, триває рівномірно чи $\epsilon$ однорідним. < .. > Задля того, щоб ця "категорія отримала дійсно культурологічну "прописку" та виросла зі свого метафоричного одягу, іiі слід зробити придатною для процедури вимірювання, надавши ії у вигляді деяких змінних" [2, 315].

Більш грунтовне розуміння поняття багатовимірності через мірність, на нашу думку, представлено Л. М. Богатою. Вона у своїх наукових розмислах виходила 3 того, що майже у всіх народів, перші одиниці вимірювання співвідносились 3 тією чи іншою частиною тіла (аршин, сажень, фут, дюйм тощо) - тобто були людиновимірними. Подальші устремління до більш точних вимірювань призвели до вибору метру у якості одиниці довжини, яка вже не залежала від особливостей людини. Це був своєрідний крок на шляху геомірності. Тим самим, людиновимірність доповнена геомірністю утворила ситуацію багатовимірності. Така ситуація вже була пов’язана з використанням мір принципово різного роду. Таким чином одним із смислів, яким можна наділити багатовимірність $€$ своєрідне подолання людиновиміріності як деякої виключної міри. Така багатовимірність $€$ багатовимірністю першого роду.

Багатовимірність другого роду витікає 3 того, що у самій людиновимірності закладено незначні але об'єктивні відхилення величини самої міри. Наприклад, факт різниці у довжині фаланга одного й того ж пальця у різних людей призводить до того, що "аршинів", "сажнів", "футів" може бути практично множина.

У ідеї багатовимірності, на думку науковця Л. Богатої, закладено дещо принципово нове. А саме те, що цілісність самого поняття "багатовимірність" передбачає одночасність здійснення різноманітних вимірів, використання різноманітних мір. Тобто багатовимірність - це "здатність одночасного вимірювання множини елементів різноманітними способами за допомогою різноманітних мір" [2, 166]. На нашу думку, таке тлумачення багатовимірності, 


\section{Вісник Національної академії керівних кадрів культури і мистецтв № 2'2о20}

дозволить просунутись до розуміння достатньо складних об'єктів, у тому числі культури.

Отже, поняття багатовимірності набуло досить різноманітних виявів у межах наукових досліджень.3 одного боку, така термінологічна невизначеність та понятійний різнобій можуть стати наріжним каменем для розвитку науки, 3 іншого - навіть спрямування фокусу уваги на уточнення поняттєвої бази багатовимірності, сприятиме виведенню наукових дисциплін за усталені межі та може стати ще одним кроком до осягнення багатовимірності культури.

Незважаючи на те, що тлумачення поняття "багатовимірність", насамперед, у філософському континумі, і не тільки, є фактично відсутнім, а сам термін, як зазначає дослідник багатовімірності, доктор філософії Л. Богатая, "не $\epsilon$ традиційним для філософського лексикону, $<\ldots>$ його пряма включеність у філософський тезаурус не визначається" [12, 135], все ж таки, філософський варіант рефлексії 3 приводу багатовимірності, на нашу думку, найбільше наблизився до іiі розуміння. Тому вважаємо, що філософські методологічні установки і принципи, засвоєння яких саме ознаменовує нинішню революцію у науковому знанні, можуть слугувати загальним орієнтиром при дослідженні культури.

Ключові поняття філософії багатовимірності в дослідженні культури. Спробу екстраполяції ключових понять філософії багатовимірності на культуру в першу чергу здійснимо через поняття "система", яке отримало надзвичайно широку сферу застосування i стало одним 3 ключових філософсько-методологічних понять. Система розглядається як сукупність взаємопов'язаних та взаємодіючих елементів, що знаходяться у певних відносинах один 3 одним і $з$ середовищем та утворюють певну цілісність та єдність. Таке визначення можна дати культурі, яка саме i $\epsilon$ надскладною, багатовимірною системою (Л. Уайт, Б. Малиновський, П. Сорокін, Т. Парсонс, М. Каган та ін.). Культура як система включає в себе низку підсистем, які уявляють собою окремі сфери культури. Як-от, наприклад, підсистема матеріальної та духовної культури, підсистема мистецтва тощо. Кожна 3 них може бути розглянута як відносно самостійна. Велика кількість вимірів породжують множину аспектів ii функціонування, кожен 3 яких може бути дослідженим, як у статиці у конкретний момент часу, так i у динаміці, еволюційному та історичному розвитку. Усі ці аспекти загальної структури культури внутрішньо взаємопов'язані між собою у межах функціонування культури як системи.

Специфіка системи не вичерпується особливостями елементів 3 яких вона складена, а пов'язана, насамперед з характером їх взаємодії.
Саме у цьому, на нашу думку, реалізується основний системний принцип - багатовимірність. Тобто бачити тенденціі, що доповнюють одна одну в прямопротилежних явищах, створювати ціле 3 непоєднуваних частин,розглядати, протилежні тенденції, які не тільки співіснують i взаємодіють, але й доповнюють одна одну, як безперервну множину. Отже багатовимірність полягає у представлені кожної тенденції як окремого виміру. У культурі ці тенденції іноді $€$ динамічними та ледь вловимими, порівняно 3 жорсткими конструкціями закономірностей. Вияв смислів певних тенденцій у конкретних соціокультурних обставинах та їх узагальнення $€$ важливою складовою культурологічного пізнання.

Система, сама по собі $€$ складним утворенням. Складність є не тільки одним 3 параметрів системи, а ключовим поняттям філософії багатовимірності. Припускаємо, що складність культури можна розглядати через філософський варіант рефлексії 3 приводу складного. Складність у плюралістичних дослідницьких зонах стимулює роздуми про багатовимірність, "бо сам факт появи складного свідчить про своєрідну вичерпність мірності, яка вже існує"[1]. Складні системи характеризуються великим числом елементів і внутрішніх зав'язків, ïх неоднорідністю і різноякісністю, структурним різноманіттям, виконують складну функцію чи ряд функцій. Вони мають дифузну організацію, тобто 3 великою кількістю змінних, між якими весь час відбуваються дифузні процеси. Також складною вважається система, яка об'єднує в собі декілька параметрів. Складність - це кількість можливих станів. Ці, та інші характеристики складності підпадають під визначення культури як складної системи. Адже культура постає як означена в історичному просторі та часі соціокультурна система, 3 притаманними їй економічним, політичним, соціальним та духовним життям. Вона включає в себе різноманітні елементи: релігію, системи політичного, економічного життя, освіту тощо, які тісно пов'язані та взаємоузгоджені. Крім того, культура має як стійкі так і змінні компоненти. До перших, наприклад, відносяться категорії культури. До других - нові покоління, ситуації, проблеми, кризові стани тощо. Культура характеризується динамічною складністю, яка виникає тоді, коли змінюються зв'язки між елементами системи. Розуміння культури як складного об'єкту, можливе лише через осягнення іï частин - самостійних елементів у їх сукупності.

Багатовимірність складної системи проявляється в функціонуванні іiі рівнів. Якщо прийняти саму ідею існування рівнів культури, то кожному з них слід підібрати ту чи іншу мірність, враховуючи характер та способи рівневого розгортання. Осмислення різноманітних рівнів 
культури знаходить своє відображення як сукупність рівнів існування буття культури (онтологічний рівень) та результатів пізнання культури (гносеологічний рівень), що i дає підстави розглядати культуру як складне явище 3 позиції багатовимірності.

Складне (від лат. complexus) буквально означає те, що $є$ зітканим, сплетено разом як єдина тканина, тобто цілісне. Цілісність є основною характеристикою культури як складної багатовимірної системи. Сенс культури як цілісності виражається через іiі багатоманітні форми - мистецтво, мораль, освіта, релігія, наука постають як цілісне. Цілісність є результатом їх постійної взаємодії, взаємовпливу та взаємозалежності. Ціле має якості, яких немає у ïx окремих складових. Інакше кажучи, дослідження культури не може зводитись до простої суми іiі складових. Культура не є сумою розрізнених феноменів. Усі вияви культури виростають 3 неї ж самої, вони постають лише у єдності з іншими виявами тієї ж культури.

Ще одним важливим моментом складних багатовимірних систем є самоорганізація. "Усіляке складне явище, яке постійно відчуває руйнування, тому i зберігається" [12, 88]. Самоорганізація - здатність складних систем до впорядкування своєї внутрішньої структури, здатність до саморозвитку, самозародження завдяки можливостям закладеним в середину системи, тобто завдяки власному потенціалу. Культура, як i будь-яка система, $\epsilon$ структурованою та ієрархічною (ціннісні, орієнтації, норми поведінки, мораль тощо). "В процесі розвитку системи починають проявляти себе ентропійні явища: знижується функціональна цілісність, системно-ієрархічна структурованість, збалансованість як окремих підсистем, так і культурного комплексу спільноти в цілому. Тобто ентропія є хаотичним та неупорядкованим станом системи культури, що з часом призводить до кризи культури - втрати ідентифікації людей, ціннісних орієнтацій, та ін. Отже, культура як система «3 рівноважного стану входить у нерівноважну фазу свого розвитку, починається процес якісної перебудови їі властивостей <..>, складається нова смислова цілісність культури, викристалізовується іiі нова парадигма. У результаті накопичення внутрішніх сил системи, ентропія досягає критичного стану, що призводить до біфуркації - стрибкоподібної якісної перебудови системи <...>. За біфуркацією настає релаксація, тобто поступове повернення системи в стан рівноваги, але вже в оновленому вигляді" [3]. Такими є, на думку дослідниці П. Гречанівської, алгоритм процесу самоорганізації культури як системи та механізми його породження.

"Конкретна історія конкретного об'єкта, є зрозумілою як низка біфуркацій 3 випадковим вибором, який відкриває різні можливості та постає як необхідна дія причини, в народжені якої значну роль відіграє випадковість. Якщо зовнішній вплив $є$ резонансним властивостям середовища, то і навіть незначний вплив здатен відіграти значну роль у долі системи. На цьому базується розуміння довільності появи нового, тобто природного перебігу розвитку (і меж цього втручання)" [12, 88]. Тобто самоорганізація як властивість культури, насамперед пов'язана зі здатністю культури розвиватися в мінливих умовах існування, особливо у кризових."Роль хаосу подібна ролі скульптора, зі здатністю відтинати від кам'яної брили (системи) все непотрібне, зайве. Тому вона $\epsilon$ необхідним елементом саморозвитку світу. Саме нестійкість виступає найважливішим моментом в процесі розвитку культури, що дає імпульс процес самоорганізації"[4]. Нова стабільність культурної системи досягається великим числом типів взаємозв'язків і взаємодій іiі елементів. Разом 3 тим порушення будь-якого типу цих зв'язків веде до втрати стійкості системи. Чим складніше організація культурної системи, тим більш імовірна втрата відносної їі стійкості.

3 усього вищесказаного очевидно, що самоорганізація культури є нелінійним процесом. Нелінійність у культурі позначає можливість несподіваних (але прогнозованих та передбачених) змін напрямків протікання процесів у культурі, їх багатоваріантність, множинність шляхів їх розгортання. I3 нелінійності шляхів еволюції культури витікає іiі багатовимірність. Нелінійність культури схожа 3 біологічною моделлю формування виду 3 випадковими мутаціями та їх природнім відбором. Така аналогія проводиться як демонстрація ролі випадковості у виборі подальших шляхів розвитку. Поняття нелінійності передбачає відмову від уявлення про причинно-наслідкові відносини процесів і подій. Нелінійна динаміка складної системи означає становлення нової фази цієї системи особливо у кризовій фазі - біфуркації (І. Пригожин, Г. Хакен, М. Ейген). Крім того, нелінійність системи допускає на певних стадіях надшвидкий розвиток процесів. При даному розумінні динамічних процесів стає ясно, що таким складним системам, як культура, не можна нав'язувати шляхи їх розвитку. Це протистоїть власним тенденціям саморозвитку складноорганізованих систем. Незважаючи на множинність шляхів еволюції (цілей розвитку) в точках біфуркації проявляється зумовленість розгортання процесів.

Слушними для розуміння культури як нелінійної системи $є$ роздуми науковця I. Добронравової. Нею вперше був введений термін нелінійне мислення як загальнонауковий стиль. "Лінійне - орієнтоване на пошук причиннонаслідкових закономірностей, а нелінійне, 


\section{Вісник Національної академії керівних кадрів культури і мистецтв № 2'2о20}

багатовимірне головною метою має проникнення до сутності обміркованого через багатовимірне поєднання смислів"[12, 135]. На іiі думку, нелінійне мислення стає образом мислення сучасної культури, адже принципи становлення, розвитку, цілісності, багатоваріативності, свободи вибору якнайкраще відповідають іï сучасному стану. Наприклад, "нелінійна структура активно у сучасній культурі використовується у зв'язку с мережею Інтернет $<. .>$. Мережеве мислення $є$ нелінійним за своєю природою<..>. Нелінійність притаманна сучасній літературі, яка проявляється у фрагментах розмаїтого тексту при розгортанні сюжету<...>. Елементи імпровізації, інтерактивності, так затребувані у сучасній культурі" [12, 88]. Нелінійність сучасної культури пов'язана викликана суттєвими сучасними трансформаціями, непередбачуваністю та насиченістю подіями, постійною мінливістю сучасності, новою динамікою соціокультурних явищ, які, найчастіше, непомітно зароджуються, спонтанно розбудовуються та зненацька стають видимими.

Погляд на культуру як нелінійну систему у дослідницьких практиках, на нашу думку, сприятиме розширенню меж наукової раціональності у дослідженнях культури. "Це не означає, що наука втрачає відмінність від інших способів духовного засвоєння дійсності. Її межі існують й можуть бути визначені загальними методологічними вимогами до теорії як продукту наукової діяльності, так i способу фіксації наукового знання" [12, 79].

Отже, філософський варіант рефлексії 3 приводу багатовимірності, який склався, дозволяє культуру розглядати як складну багатовимірну нелінійну систему, яка характеризується здатністю зберігати себе як єдине ціле, і здатністю постійно оновлювати себе - самоорганізовуватись. Але, незважаючи на значний потенціал філософії багатовимірності, можемо констатувати, що у культурології його можна використовувати, в більшій мірі, метафорично, оскільки адекватного інструментарію для гуманітарної сфери на сьогоднішній момент не вироблено.

Специффіка багатовимірності у методологіі культурологіi. Застосування багатовимірного методу у культурології обумовлюються низкою принципових моментів. По-перше, культурологія як окрема галузь наукового знання, ще знаходиться в процесі свого становлення. Подруге, специфіка культури, яка постійно змінюється, розвивається та $є$ надскладною системою, певною мірою визначає специфіку культурології як гуманітарної науки - ïi теоретичні постулати які найчастіше формулюються як гіпотези, мають вірогідній характер. Відсутність єдиного підходу щодо визначення поняття культури, розмиває предметне поле культурології. Багатовимірність явищ культури, значний масив різнопланових культурологічних досліджень спричиняють велику кількість способів і тлумачень самої культурології і культурологічного знання. Потретє, дискусійним є характер визначення об'єкту i предмету культурології. Кожний напрям в дослідженні культури послуговується лише своїм робочим визначенням, відтак досліджуваний об'єкт - культура постає виразником множини вимірів. Крім того, кожен об'єкт, річ, явище культури є невичерпними в своїх відношеннях. Знаходячись в різних умовах об'єкт по-різному себе виявляє. Також невизначеним, на нашу думку, є розуміння міри, за допомогою якої вимірюється культура. Адже культура не може бути вимірною за допомогою традиційних метричних систем, які знаходяться у арсеналі природничих наук. Вірніше кажучи, такі виміри мало що дадуть у сенсі іï осягнення. Необхідно відшукувати інші "лінійки" та інші способи вимірювання. На сьогодні відома лише одна універсальна "лінійка" запропонована давньогрецьким софістом Протагором, який говорив про людину "як міру всіх речей", вбачаючи особливість людського в своєрідній єдності та взаємозалежності людини. Адже культура твориться людиною і поза людини не існує, вона не $є$ чимось зовнішнім стосовно людини, вона вплетена в їі буття. Але лише однієї людиновимірності, безумовно, буде замало для осягнення культури. Сподіваємось, що концептуалізація кожної 3 множини таких вимірностей та вироблення конкретного дослідницького інструментарію, ще попереду.

I нарешті, ще один ключовий момент багатовимірності дослідження культури. Він полягає у врахуванні дослідницької специфіки культуролога, як інтерпретатора культури. Якщо філософія до "модальності суб'єкту є байдужою" $[5,62]$, то зовсім інакшою $є$ справа у культурології, адже вона має справу з особливим суб'єктом і поглядом на культуру не ззовні, а 3 середини. "Міра за допомогою якої здійснюється процедура вимірювання, передбачає наявність того, хто цю міру вибирає та здійснює виміри $<\ldots>$ Той, хто вимірює і те, що вимірюється є взаємопов'язаними" [12, 164-166]. Особистість дослідника у цьому сенсі, постає як нова «мірність» культури. Адже, культурологічне знання, яке представлено множиною дискурсів і аспектів інтерпретацій цієї реальності, одночасно охоплює ціле 3 вичерпною багатовимірністю i багатозначністю, тим самим наближується до реального об' єкта у всій його складності. Разом 3 тим, представлена у кожному випадку картина культури є одним з можливих (багаточисельних) зрізів культурного цілого, що цілком відповідає багатовимірній та багатозначній природі 
культури, та має нескінчену кількість дефініцій та описів. А головне - представлена картина культури у кожному конкретному випадку - це лише надбання суб'єкта культури (дослідникакультуролога), яке характеризується певною (суб'єктною) точкою зору, світоглядною та смисловою позицією, певною мовою. У цьому сенсі М. Бахтін був правий: усі феномени культури так чи інакше пізнаються через світ суб'єкта. Отже суб'єкт постає як певна міра, розуміння i пояснення культури. I в цьому криється принципова відмінність багатовимірності у методології культурології.

Висновки. Філософські методологічні установки i принципи, засвоєння яких саме ознаменовує нинішню революцію у науковому знанні, можуть слугувати загальним орієнтиром при дослідженні культури. В контексті філософії багатовимірності культура постає як складна багатовимірна нелінійна система, яка характеризується здатністю зберігати себе як єдине ціле, і здатністю постійно оновлювати себе - самоорганізовуватись. Філософський варіант рефлексії з приводу багато вимірності пропонує розуміти багатовимірність як здатність одночасного вимірювання множини елементів різноманітними способами за допомогою різноманітних мір. Цей метод може стати ще одним кроком до осягнення багатовимірності культури. Проте у культурології його можна використовувати, в більшій мірі, метафорично, оскільки адекватного інструментарію на сьогоднішній момент ще не вироблено. Метод багатовимірного дослідження культури може застосовуватись 3 врахуванням, по-перше, неусталеності культурології як окремої галузі наукового знання та розмитості їі предметного поля; по-друге, - специфіки культури як виразника множинності вимірів та водночас невизначеності міри культури; по-третє, 3 врахуванням виміру культури через смислову позицію іiі інтерпретатора - суб' єкта (дослідникакультуролога).

Отже, здійснена спроба наукової розвідки лише окреслила шляхи i дослідницькі перспективи багатовимірності у культурології. Вірогідно, що більш детальне іiі осмислення ще попереду. Вважаємо, що декларований нами багатовимірний метод, має значний потенціал, а його подальша розробка та втілення у дослідницьку практику дозволить суттєво розширити методологічну базу культурології.

\section{Jimepamypa}

1.Богатая Л.Н. Многомерное мышление в контексте представлений о многомерности. Ученые записки Таврического наџионального университета им. В.И. Вернадского. 2010. №1. С. 41-45.

2.Бекарев А. М., Бурнашев К. Э. Многомерность социального пространства: организационно- управленческий контекст. Вестник Нижегородского университета им. Н.И. Лобачевского. 2009, № 4, С. 312316.

3.Гречанівська П.Е. Аналіз культури у парадигмі теорії систем. Вісник Національної академії керівних кадрів культури і мистецттв. 2017. № 1. С.3-7.

4.МоисеєвН. Н. Алгоритмы развития. 1987.304 с.

5.Каган, М.С. Системный подход и гуманитарное знание. 1991. $384 \mathrm{c}$.

6.Соціологія: підручник / за ред. В.Г. Городяненка. К.: Академія, 2008. 544 с.

7..Философия мышления: сборник статей / ред.кол. Л.Н.Богатая (отв. ред.), И.С. Добронравова, Ф.В.Лазарев. Одесса: Печатный дом, 2013. 444 с.

8. Філософський енциклопедичний словник / ред. В. І. Шинкарук. К., 2002. 742 с.

\section{References}

1.Bogataya, L.N. (2010). Multidimensional thinking in the context of ideas about multidimensionality. Scientific notes of the Tauride National University named after V.I. Vernadsky. Series Philosophy. Culturology, 1, 41-45. [in Russian].

2.Bekarev, A.M., Burnashev, K.E. (2009). Multidimensionality of social space: organizational and managerial context. Sociology. Psychology. Philosophy Bulletin of Nizhny Novgorod University named after N.I. Lobachevsky, 4, 312-316. [in Russian].

3.Hrechanivs'ka, P.E. (2017). Analysis of culture in the theory of systems paradigm. Bulletin of the National Academy of Cultural and Arts Leaders: Scientific Journal. Kyiv: Millennium, 1. [in Ukrainian].

4.Moyiseyev, N.N. (1987). Algorithms of development. Moscow: Science.[in Russian].

5.Kagan, M.S. (1991). Systems approach and humanitarian knowledge; Selected Articles. Leningrad: Publishing House of the Leningrad University.[in Russian].

6.Gorodjanenko, V.G. (ed.) (2008). Sociology: Textbook. Kyiv: EC Academy. [in Ukrainian].

7.Bogataya, L.N. (ed.) (2013). Philosophy of thinking: a collection of articles. Odessa: Printing house.[in Russian].

8.Shynkaruk, V.I. (ed.) (2002). Philosophical Encyclopedic Dictionary. Kyiv: Abris, VI. [in Ukrainian].

Стаття надійила до редакиії 10.04.2020 Прийнято до друку 12.05.2020 